\title{
Spectrum of ectopic pregnancy in tertiary care centre
}

\author{
Ishrat Zuber, Vaishali Chaurasia*
}

Department of Obstetrics and Gynecology, Chirayu Medical College and Hospital, Bhopal, Madhya Pradesh, India

Received: 29 December 2017

Accepted: 31 January 2018

\section{*Correspondence:}

Dr. Vaishali Chaurasia,

E-mail: vaishalilikhar91@gmail.com

Copyright: (C) the author(s), publisher and licensee Medip Academy. This is an open-access article distributed under the terms of the Creative Commons Attribution Non-Commercial License, which permits unrestricted non-commercial use, distribution, and reproduction in any medium, provided the original work is properly cited.

\section{ABSTRACT}

Background: Ectopic pregnancy is a catastrophic and life-threatening condition and one of the commonest acute abdominal emergency in day-to-day practice. Objectives of present study were to know the incidence of Ectopic pregnancy at Tertiary care centre, the age group, parity and risk factor of ectopic pregnancy, the clinical presentation of ectopic pregnancy and the outcome and management of ectopic pregnancy.

Methods: It was a retrospective study conducted at Chirayu Medical College and Hospital, Bhopal from $1^{\text {st }}$ June 2009 to $31^{\text {st }}$ May 2014. A total of 42 patients with ectopic pregnancy were analyzed on clinical presentation, clinical findings, investigations, operative findings and outcome.

Results: A majority of women (64.29\%) were in the age group of $21-30$ years and $78.57 \%$ were multigravida. Commonest risk factors were previous history of abortion $(23.80 \%)$ and pelvic inflammatory disease $(14.28 \%)$ Amenorrhea $(92.85 \%)$ and pain abdomen $(89.22 \%)$ were the most common presenting symptoms. Ampulla of fallopian tube was the commonest site $(45.23 \%)$. Unilateral salpingectomy was performed in $40.47 \%$ patients. There were no maternal deaths and majority $(80.96 \%)$ were discharged within seven days.

Conclusions: Ectopic pregnancy still remains one of the major causes of maternal morbidity and mortality. Early diagnosis and referral in hemodynamically stable state along with use of minimal access surgery or medical management can change the scenario of ectopic pregnancy in the developing world.

Keywords: Amenorrhoea, Abortion, Ectopic, Pregnancy, Pelvic inflammatory disease

\section{INTRODUCTION}

The key to the progress of a country lies in reducing its maternal and child mortality and morbidity. Over the years, Government of India has taken many initiatives. The visibility of NRHM, now called National Health Mission, is reflected in progress towards achieving targets for the reduction of Maternal Mortality Rate (MMR), Infant Mortality Rate (IMR), Total fertility Rate (TFR) and other indicators.

Launch of Janani Surkasha Yojna (JSY) scheme and Janani- Shishu Suraksha Katyakram (JSSK) in 2011 has further strengthened maternal health initiatives by entitling free deliveries and Caesarean-Sections to every pregnant woman coming for deliveries at government health facility.

Last year, heath ministry launched an innovate scheme to provide free health check-ups to pregnant women at government health centres and hospitals by private doctors under The Pradhan Mantri Surakshit Matritva Abhiyan.

Popularly referred to as 'I pledge for 9' that was announced by Prime Minister Narendra Modi during his monthly radio address Mann Ki Baat, invites the private sector to provide free ante-natal services $(A N C)$ on the $9^{\text {th }}$ 
of every month on a voluntary basis to pregnant women, especially those living in underserved, semi-urban, poor and rural areas

Ectopic pregnancy is the leading cause of maternal death during the first trimester of pregnancy, accounting for approximately $10 \%$ of all pregnancy-related deaths. ${ }^{1}$ It remains to be a condition presenting as a serious health problem for women of childbearing age. ${ }^{2}$ It has been shown to reduce subsequent fertility and increase the chances of subsequent ectopic pregnancy. ${ }^{3}$ Over recent decades, there has been a rise in the incidence of ectopic pregnancy. $^{4}$

There is extensive literature regarding the potential risk factors for ectopic pregnancy. The identified risk factors for ectopic pregnancy include age, previous ectopic pregnancy, previous pelvic surgery, use of intrauterine contraceptive devices, female sterilization, history of pelvic inflammatory disease, history of infertility and smoking at the time of conception. ${ }^{5}$ The increased awareness and knowledge on the risk factors for could enable an early and accurate diagnosis of the disease, resulting in a reduced need for surgery and fewer complications.

Ectopic pregnancy is defined as implantation of fertilized ovum other than normal site of uterine cavity, which is in conductive of its growth and development. ${ }^{6}$ The possible contribution of pelvic inflammatory disease and intra uterine contraceptive devices have been cited as major risk factors. ${ }^{7}$

The evaluation includes a combination of determination of urine and serum human chorionic gonadotrophin (hCG) levels. Key to the diagnosis is determination of the presence or absence of an intrauterine gestational sac correlated with serum $\beta$-hCG levels allows ectopic pregnancy to be identified before the development of life threatening events.

In present scenario with the availability of diagnostic modalities like Trans vaginal sonography most of the cases are diagnosed early and conservative management of these pregnancies either medically or with conservative surgical approach, preferably laparoscopy is possible but in patients who report late in shock, laparotomy and at times salpingectomy remains the only option.

\section{METHODS}

This was a retrospective study done at Chirayu Medical College and hospital Bhopal. The case records of the patients with ectopic pregnancy admitted between $1^{\text {st }}$ April 2015 to $31^{\text {st }}$ March 2017 were traced from medical records department and operation theatre registers, after approval from research committee of the hospital. All the relevant information with respect to demographic profile, clinical presentation, risk factors, management were noted in preformed proforma and analysed in detail.

\section{Inclusion criteria}

All patients diagnosed as ectopic pregnancy in admission files and operation theatre records were included in the study.

\section{Exclusion criteria}

- Patients diagnosed as having intrauterine pregnancy

- Patients of ectopic pregnancy having chronic medical disorders.

\section{RESULTS}

In this study, maximum (64.5\%) patients were in 21-30 yrs age group. This corresponds to the trend of early marriage and early conception in India. $26.19 \%$ patients were in 31-35 year age group. Both more than 35 years and less than 2 years age group had $4.76 \%$ cases.

Table 1: Distribution of cases according to age.

\begin{tabular}{|lcl|}
\hline Age & Number & Percentage \\
\hline$<20 y r s$ & 02 & 4.76 \\
\hline $21-30 y r s$ & 27 & 64.29 \\
\hline $31-35 y r s$ & 11 & 26.19 \\
\hline $36-40 y r s$ & 02 & 4.76 \\
\hline Total & 42 & 100 \\
\hline
\end{tabular}

In current study, $78.57 \%$ patients were multigravida, while only $21.43 \%$ were primigravida.

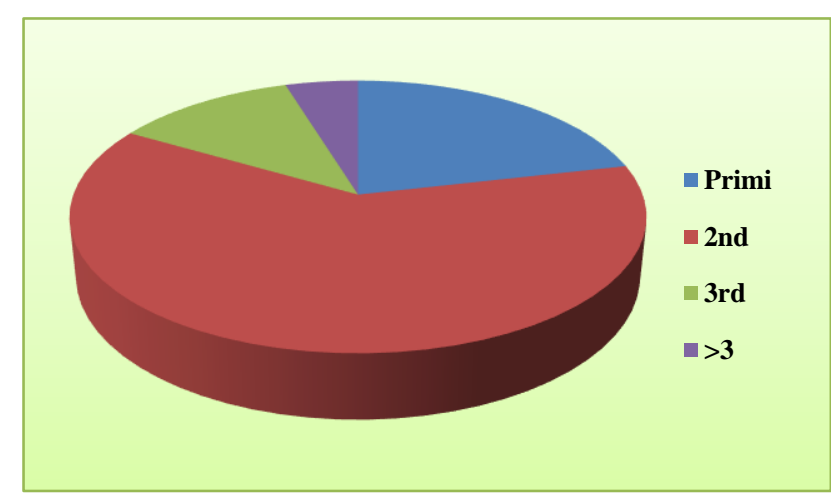

Figure 1: Distribution of cases according to obstetric history.

In this study, most common presentation was amenorrhea, found in $92.85 \%$ patients while abdominal pain was present in $89.22 \%$ cases. $36.34 \%$ patients presented with bleeding per vagina. The classical triad of amenorrhea, abdominal pain and vaginal bleeding was seen in $12.82 \%$ cases. $11.06 \%$ patients presented with other complaints like giddiness, vomiting and fainting attacks. 
Table 2: Distribution of cases according to clinical presentation.

\begin{tabular}{|lll|}
\hline Symptom & Number & Percentage \\
\hline Amenorrhoea & 39 & 92.85 \\
\hline Pain abdomen & 37 & 89.22 \\
\hline Bleeding per vagina & 15 & 36.34 \\
\hline others & 05 & 11.06 \\
\hline
\end{tabular}

Table 3: Distribution of cases according to clinical examination.

\begin{tabular}{lll} 
Finding & Number & Percentage \\
\hline Abdominal tenderness & 14 & 33.33 \\
\hline Adenexal mass & 08 & 19.05 \\
\hline Abdominal distension & 07 & 16.67 \\
\hline Cervical motion tenderness & 10 & 23.80 \\
\hline shock & 04 & 09.52 \\
\hline
\end{tabular}

In present study abdominal tenderness was present in $33.33 \%$ cases, cervical motion tenderness was found in $23.80 \%$ patients. $19.05 \%$ cases had adenexal mass on per vaginum examination. Abdominal distention was present in $16.67 \%$ cases. Only $9.52 \%$ patients came in shock.

Table 4: Distribution of cases according to risk factors.

\begin{tabular}{lcl} 
Risk factors & $\begin{array}{c}\text { Number } \\
(\mathbf{N} 42)\end{array}$ & Percentage \\
\hline $\begin{array}{l}\text { History of abortion } \\
\text { History of previous } \\
\text { ectopic pregnancy }\end{array}$ & 02 & 23.80 \\
\hline $\begin{array}{l}\text { History of PID } \\
\text { Previous LSCS }\end{array}$ & 06 & 4.76 \\
$\begin{array}{l}\text { History of PPH in } \\
\text { previous pregnancy }\end{array}$ & 02 & 14.28 \\
\hline $\begin{array}{l}\text { History of infertility } \\
\text { History of intra uterine } \\
\text { contraceptive device } \\
\text { insertion }\end{array}$ & 02 & 4.14 \\
\hline $\begin{array}{l}\text { History of tubal surgery } \\
\text { History of MTP pill } \\
\text { uptake in present } \\
\text { pregnancy }\end{array}$ & 03 & 4.76 \\
\hline
\end{tabular}

In present study, previous history of abortion (23.80\%), and PID (14.28\%) were the commonest risk factors associated with ectopic pregnancy.

History of Intrauterine contraceptive device insertion was present in $9.52 \%$ patients. Incidence of both, tubal surgery and MTP pill uptake in present pregnancy was similar i. e. $7.14 \%$ each.

History of previous LSCS was present in $7.14 \%$ cases while $4.76 \%$ patients had history of post-partum hemorrhage in previous pregnancy. History of infertility was found in $2(4.76 \%)$ cases. Similarly, 2 patients $(4.76 \%)$ had history of previous ectopic pregnancy.

Table 5: Distribution of cases according to management.

\begin{tabular}{|lll|}
\hline Management & No. & Percentage \\
\hline Unilateral salpingectomy & 17 & 40.47 \\
\hline Unilateral salpingoopherectomy & 11 & 26.19 \\
\hline $\begin{array}{l}\text { Unilateral salpingectomy/ } \\
\text { salpingoopherectomy with TT }\end{array}$ & 06 & 14.29 \\
\hline Milking of tube & 01 & 2.39 \\
\hline $\begin{array}{l}\text { Segmental resection and } \\
\text { anastomosis }\end{array}$ & 03 & 7.14 \\
\hline Segmental cornual resection & 02 & 4.76 \\
\hline Medical m/m & 02 & 4.76 \\
\hline
\end{tabular}

In present study, unilateral salpingectomy was the most commonly performed procedure $(40.47 \%)$, followed by Unilateral salpingoophorectomy. This is in correspondence with the commonest presentation being chronic ectopic pregnancy. Tubectomy of the other side was performed in $14.29 \%$ patients. Segmental resection and anastomosis was done in $7.14 \%$ cases. $4.76 \%$ patients underwent cornual resection. Milking of tube was done in one patient while $2(4.76 \%)$ patients were given medical management with monitoring after admission.

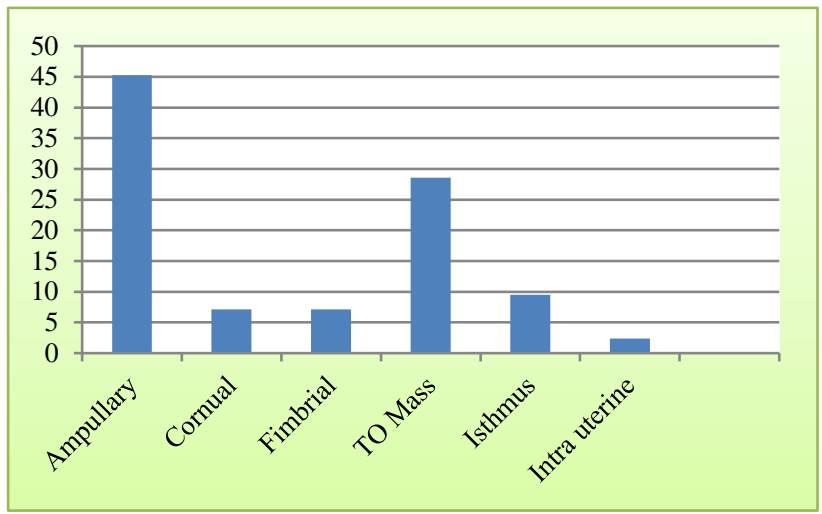

Figure 2: Distribution of cases according to the anatomical location of ectopic pregnancy.

In present study, most common site of ectopic pregnancy was ampullary (45.23\%). TO mass was present in $28.57 \%$ cases followed by Isthmic $9.52 \%$, while both, cornual and fimbrial implantation was present in $7.14 \%$ cases each.

In present study, commonest finding was chronic ectopic (33.33\%), followed by acute ruptured (26.19\%), tubal abortion (19.05\%) and unruptured variety (16.67\%). One case was diagnosed incidentally, while one suspected case turned out to be intrauterine pregnancy during laparoscopy. 
Table 6: Distribution of cases according to intra operative findings.

\begin{tabular}{|lll|}
\hline Finding & $\begin{array}{c}\text { Number } \\
(\mathbf{N} 42)\end{array}$ & Percent \\
\hline $\begin{array}{l}\text { Acute ruptured ectopic } \\
\text { pregnancy }\end{array}$ & 11 & 26.19 \\
\hline Unruptured ectopic pregnancy & 07 & 16.67 \\
\hline Tubal abortion & 08 & 19.05 \\
\hline Chronic ectopic pregnancy & 14 & 33.33 \\
\hline Incidental finding & 01 & 2.38 \\
\hline Negative laparoscopy & 01 & 2.38 \\
\hline Total & 42 & 100 \\
\hline
\end{tabular}

In present study, $23.81 \%$ patients were discharged within 48 hours. Majority of these had undergone laparoscopic surgery. $57.15 \%$ patients were discharged within 3 to 7 days while only $19.04 \%$ patients required prolonged stay of more than 7 days.

Table 7: Distribution of cases according to duration of hospital stay.

\begin{tabular}{|lcl|}
\hline Duration & Number (N 42) & Percentage (\%) \\
\hline$<48$ hrs & 10 & 23.81 \\
\hline 3-7days & 24 & 57.15 \\
\hline$>$ 7days & 08 & 19.04 \\
\hline Total & 42 & 100 \\
\hline
\end{tabular}

\section{DISCUSSION}

Total obstetric admissions during the study period 2,577, of which 42 cases were ectopic pregnancy. The incidence came out to be $1.63 \%$.

Majority of women $(64.29 \%)$ in present study group belonged to the age group of 21- 30 years, which is close to the studies done by Mufti S et al. (75.4\%) and Panchal $\mathrm{D}$ et al $(71.66 \%){ }^{8,9}$ This is due to the trend of early marriages in India.

Majority of patients (78.57\%) were multigravida in present study. Similar results were obtained in studies by Panchal D et al, Prassana B et al and Shraddha shetty K et al, where respectively $81.66 \%, 84 \%$, and $83.9 \%$ patients were multigravida. ${ }^{9-11}$ In study by Shukla DB et al, the number of primigravida (43.14\%) and multigravida $(56.86 \%)$ were comparable. ${ }^{12}$

In present study $32 \%$ patients did not have any risk factors. History of PID was present in $14.28 \%$ of the cases. This is correlating with the study done by Bhavna, et al where history of PID was present in $22.7 \%$ of the cases with ectopic pregnancy. ${ }^{13}$ PID causes damage of tubal mucosa and peritubal adhesions leading to hindrance in transportation of embryo.

In the present study $23.80 \%$ of patients had history of previous abortion which is close to the study done by
Rose Jophy et al and higher than studies by Khaleeque $\mathrm{F}$ et al $(12.9 \%)^{14,15}$ Post-abortal infections cause tubal damage .It is mostly seen in cases of illegal abortions..

In present study, history of infertility was present in $4.76 \%$ cases, which is correlating with the studies done by Panchal D et al (11.66\%) and Mufti S et al. (8.77\%). ${ }^{8,9}$ The association between infertility, previous pelvic infection and tubal pathology is the possible explanation.

In present study $4.76 \%$ of the women had history of previous ectopic pregnancy, which is correlating with the studies done by Mufti S et al (5.26\%), Uzma Shabab U et al $(5 \%)$ and Prasanna B et al $(6 \%) .{ }^{8,10,16}$ In present study $7.14 \%$ of the women with ectopic pregnancy had tubal surgery which correlates with the studies done by Shabab $\mathrm{U}$ et al which was (5\%) and Shrestha, et al (5\%). ${ }^{16,17}$

In present study, 9.52\% of women with IUCD had ectopic pregnancy which correlates with the studies done by Shetty SK, et al. (6.4\%), Shrestha et al (5\%) and Fageeh WM (5.8\%). ${ }^{11,17,18}$ IUCD has no effect on ovulation, it prevents intrauterine pregnancy but does not prevent tubal and ovarian pregnancy. Hence the risk of tubal pregnancy is more if a woman conceives with IUCD in situ.

The classical triad of pain in abdomen, amenorrhea and vaginal bleeding was not seen in all the cases. In the present study, $76 \%$ of the patients had history of amenorrhea, 90\% had pain abdomen and 36.34\% had bleeding per vagina. Similar results were found in the study done by Gupta $\mathrm{R}$ et al in which amenorrhea was present in $90 \%$, pain abdomen in $87.5 \%$ and bleeding per vagina in $67.5 \%$ of the patients. ${ }^{19}$ Urine pregnancy test was positive in $97.61 \%$ patients which corresponds to the study done by Gaddagi et al RA Two patient were brought in shock with significant intra peritoneal hemorrhage. ${ }^{20}$

Ampulla was the most common anatomical location seen in $19(45.23 \%)$ cases. similarly, study done by Rashmi Gaddai et al had $8.57 \%$ cases with tubo ovarian mass as they were chronic ectopic pregnancies. ${ }^{15}$

Majority of patients in study were managed surgically. Among surgically treated patients, 23 had unilateral salpingectomy out of which 6 patients had tubectomy of opposite tube. 11 patients underwent unilateral salpingoophrectomy for chronic Tubo-ovarian mass. Tubal expression of ectopic gestation by milking of tube was done in one patient. Similar result was seen in study done by Khaleeque R et al. ${ }^{9}$ Segmental cornual resection was done in 2 patients. Laparoscopic surgery was done in 14 cases, rest 28 patient underwent open surgery.

2 case were managed medically with single dose of intramuscular methotraxate, and serum beta HCG monitoring successfully. This is due to the fact that ours is a tertiary care centre where majority are referred cases. 


\section{CONCLUSION}

The incidence of ectopic pregnancies is on rise. Identification of underlying risk factors, high suspicion, early diagnosis with the modern aids like trans vaginal ultrasound and serum beta-hCG levels, timely intervention in the form of medical or surgical treatment will definitely help in reducing the morbidity and mortality associated with ectopic pregnancy and in improving the future reproductive outcome. Laparoscopy is a better modality of treatment as it has faster recovery and is associated with early discharge from hospital in comparision to patients who undergo laparotomy.

Funding: No funding sources

Conflict of interest: None declared

Ethical approval: The study was approved by the Institutional Ethics Committee

\section{REFERENCES}

1. Farquhar CM. Ectopic pregnancy. Lancet. 2005;366(9485):583-91.

2. Zane SB, Kieke BJ, Kendrick JS, Bruce C. Surveillance in a time of changing health care practices: estimating ectopic pregnancy incidence in the United States. Matern Child Health J. 2002;6(4):227-36.

3. Chow WH, Daling JR, Cates WJ, Greenberg RS. Epidemiology of ectopic pregnancy. Epidemiol Rev. 1987;9:70-94.

4. Walker JJ. Ectopic pregnancy. Clin Obstet Gynecol. 2007;50(1):89-99.

5. Yuk JS, Kim YJ, Hur JY, Shin JH. Association between socioeconomic status and ectopic pregnancy rate in the Republic of Korea. Int J Gynaecol Obstet. 2013;122(2):104-7.

6. Udigwe GO, Umeononihu OS, Mbachu II. Ectopic pregnancy: a 5 year review of cases at Nnamdi Azikiwe university teaching hospital (NAUTH) Nnewi. Niger Med J. 2010;51:160-3

7. Musa J, Daru PH, Mutihir JT, Ujah IA. Ectopic pregnancy in Jos Northern Nigeria: Prevalence and impact on subsequent fertility. Niger $\mathbf{J}$ Med. 2009; $18: 35-8$

8. Samiya M, Shagufta R, Samina M, Reyaz AR, Wasiqa K. Ectopic pregnancy: an analysis of 114 cases. JK Practitioner. 2012;17(4):20-3.
9. Panchal D, Vaishnav G, Solanki K. Study of management in patient with ectopic pregnancy. National J Integrated Res Med. 2011;2(3):91-4.

10. Prasanna B, Jhansi CB, Swathi K, Shaik MV. A study on risk factors and clinical presentation of ectopic pregnancy in women attending a tertiary care centre. Int Archives Int Med. 2016;3(1):90-6.

11. Shetty S, Shetty A. A clinical study of ectopic pregnancies in a tertiary care hospital of Mangalore, India. Innov J Med Health Sci. 2014;4(1):305-9.

12. Shukla DB, Jagtap SV, Kale PP, Thakkar HN. Study of ectopic pregnancy in a tertiary care centre. Int $\mathbf{J}$ Reprod Contracept Obstet Gynecol. 2017 Mar,6(3):975-979.

13. Bhavna, Gupta KB, Pathania K, Jindal M, Vohra R, Ahmed M. Risk factors for ectopic pregnancy: a case control study in tertiary care centre. JDMS. 2014;13(3): 23-7.

14. Jophy R, Thomas A. Ectopic pregnancy 5 years' experience. J Obstet Gynecol India. 2002;52(4):55-8.

15. Khaleeque F, Siddiqui RI, Jafarey SN. Ectopic pregnancies: A Three year study. J Pak Med Assoc. 2001;51:240-3

16. Shabab U, Hashmi HA. Different pattern of presentation of ectopic pregnancy and its management. J Surg Pak. 2013:18-19.

17. Shrestha J, Saha R. Comparison of laparoscopy and laparotomy in the surgical management of ectopic pregnancy. J Coll Physicians Surg Pak. 2012;22:7604.

18. Fageeh WM. Diagnosis and management of ectopic pregnancy in King Abdulaziz University Hospital: A Four Year Experience. Medical Science. 2008;15(2).

19. Gupta R, Porwal S, Swarnkar M, Sharma N, Maheshwari P. Incidence, trends and risk factors for Ectopic Pregnancies in a tertiary care hospital of Rajasthan. J Pharm Biomed Sci., 2012; 16(07).

20. Rashmi A, Gaddagi AP, Chandrasekar. A clinical study on ectopic pregnancy. J Clinic Diag Res. 2012;6(5):867-9.

Cite this article as: Zuber I, Chaurasia V. Spectrum of ectopic pregnancy in tertiary care centre. Int $\mathbf{J}$ Reprod Contracept ObstetGynecol 2018;7:1435-9. 